\title{
NILAI-NILAI PENDIDIKAN DALAM SEJARAH PENURUNAN AL-QUR`AN SECARA BERTAHAP
}

Nur Hidayat

Dosen Fakultas Ilmu Tarbiyah dan Keguruan UIN Sunan Kalijaga Yogyakarta alamat email. Bos_hidayat@yahoo.com

\begin{abstract}
Abstrak
Pembahasan tentang sejarah singkat Quran akan membuka cakrawala baru bagi para ilmuwan yang ingin selalu mengkaji dan memahaminya dalam setiap kesempatan waktu yang ada. Disini dapat kita garis bawahi bahwa Quran merupakan wahyu Allah yang disampaikan kepada Nabi Muhammad SAW melalui malaikat Jibril dari lauhul mahfud. Disamping itu juga, Quran merupakan sumber beberapa ilmu pengetahuan yang harus selalu digali dengan cermat dan mendalam, karena akan dapat memunculkan ilmu-ilmu baru setelah diadakan penelitian yang mendalam.

Diturunkannya Quran secara bertahap selama 23 tahun akan memberikan pembelajaran bagi umat Islam agark mudah dihafal dan dipahami dengan baik. Disamping itu, sebagai pelajaran bagi para ilmuwan untuk selalu mengikuti pada setiap kasus dilapangan yang dihadapi segera dapat ditemukan jawabannya dengan pasti dan benar. Sisi lain juga merupakan pedoman bagi seorang pendidik dalam menyampaikan suatu ilmu pengetahuan kepada siswa atau murid secara tahapan yang benar sesuai dengan tingkat usia pendidikannya.
\end{abstract}

Kata kunci: Sejarah Quran, Wahyu, dan Nilai Pendidikan.

\section{Abstract}

Brief discussion of the history of the Quran will open new horizons for scientists who want to always examine and understand it in every time there is a chance. Here, we can underline that the Koran is the revelation of God which was delivered to the Prophet Muhammad through the Gabriel from Lawh Mahfud. Besides, the Quran is the source of some of the science that should always be explored carefully and deeply, because it will be able to bring new knowledge once held in-depth research.

Quran lowered gradually over 23 years will provide learning for Muslims in order to easily memorized and understood. In addition, as a lesson for scientists to keep up on the field facing each case can be found immediately and correct answer with certainty. The other side is also a guide for educators in delivering a science to students or pupils are the steps necessary in accordance with the age level of education.

Keywords: History of the Quran, Revelation, and Value of Education. 


\section{Pendahuluan}

Dari tema di atas, penulis ingin menyampaikan beberapa nilai pendidikan yang terkandung dalam penurunan kitab suci Al-Quran secara bertahap. Disini, kalau kita mau menelaah dan mendalami tentang isi kandungan Qur’an dari berbagai aspek akan selalu menarik untuk dikaji dan dikembangkan secara lebih luas. Semakin seseorang menekuni dan mendalami isi kandungan kitab suci Al-Quran maka ia akan semakin bertambah wawasan dan ilmu pengetahuan tentang cakrawala kehidupan yang lebih luas. Karena Quran merupakan sumber dari segala sumber ilmu pengetahuan yang menyangkut masalah kehidupan manusia dari segala aspek dan sisi kehidupan, baik kehidupan didunia maupun kehidupan diakhirat.

Al-Quran adalah mukjizat Islam yang kekal dan mukjizatnya selalu diperkuat oleh perkembangan dan kemajuan ilmu pengetahuan dan teknologi yang semakin dasyat. Ia diturunkan Allah kepada Rasulullah, Muhammad Saw untuk mengeluarkan manusia dari suasana yang gelap (jahiliyah) menuju yang terang yaitu agama Islam yang rahmatan lil alamin dan membimbing mereka kejalan yang lurus. Disinilah, diri Rasulullah SAW menyampaikan isi kandungan Quran itu kepada para Sahabatnya dan orang-orang Arab asli, sehingga mereka dapat memahaminya berdasarkan naluri bangsa mereka sendiri. Apabila mereka menemukan keraguan dan ketidakjelasan dalam memahami suatu ayat, maka mereka dapat menanyakannya langsung kepada diri Rasulullah SAW (Manna Khalil al-Qattan, 1996:1).

Tetapi yang menjadi persoalannya ialah kita umat Islam yang sudah jauh masanya dengan Nabi dan tidak memahami bahasa Arab dengan baik, seperti bangsa kita Indonesia. Disamping itu maukah dan mampukah seseorang membaca memahami, menganalisa dan menggali isi kandungan yang ada dalam Qur`an? Disamping itu kalau ingin mendalami isi kandungan Qur`an dengan baik, maka seharusnya seseorang memahami dahulu apa itu Qur`an bagaimana sejarahnya dan mengapa Qur`an diturunkan secara berangsur-angsur dan aspek penting lainnya yang memang harus dipahami lebih mendalam. 
Kemudian di sini, Sebelum menguraikan bukti-bukti sejarah, akan dikutipkan pendapat seorang ulama besar Syi`ah kontemporer, Muhammad Husain AlThabathaba`iy, beliau menyatakan bahwa sejarah Qur`an demikian jelas dan terbuka, sejak turunnya sampai masa sekarang ini. Ia dibaca oleh kaum muslimin sejak dahulu sampai sekarang, sehingga pada hakikatnya Qur`an tidak membutuhkan sejarah untuk membuktikan keotentikannya. Karena kitab suci tersebut lanjut Thabathaba iy memperkenalkan dirinya sebagai firman Allah dan membuktikan hal tersebut dengan menantang siapa pun untuk menyusun seperti keadaannya.

Dari sinilah, bagi kita sudah cukup menjadi bukti walaupun tanpa bukti-bukti sejarah (M. Quraish Shihab, 2009: 28). Salah satu bukti bahwa Qur`an yang berada ditangan kita sekarang ini adalah, Qur`an yang turun kepada Nabi SAW tanpa pergantian dan perubahan adalah berkaitan dengan sifat dan ciri-ciri yang diperkenalkannya menyangkut dirinya yang tetap asli dan utuh dapat ditemui sebagaimana keadaannya aslinya pada masa dahulu.

Dalam artikel ini, penulis ingin memperkenalkan kepada para pembaca dan pencinta ilmu pengetahuan, bahwa dibalik penurunan Al-Qur`an secara berangsurangsur dan bertahap mengandung makna pendidikan yang perlu dikembangkan dan direalisasikan kepada anak didik, dari tingkat bawah sampai pada tingkat atas. Realitas yang ada sekarang ini bahwa anak dizaman sekarang sedang banyak mengahadapi problem dalam menguasai suatu ilmu, yaitu mereka punya pandangan dan keinginan untuk mendapatkan suatu ilmu tapi belum menyadari dengan sepenuhnya mengikuti jalan secara bertahap dan berangsur-angsur.

\section{Fenomena Pewahyuan}

Secara etimologi, kata ini mengandung dua pengertian dasar, yaitu tersembunyi, dan cepat (Hasbi Ash-Shiddieqy, 1980: 27). Akan tetapi kata ini dapat dimaknai sebagaimana statusnya sebagai kata benda pasif yaitu yang diwahyukan. Wahyu adalah isyarat yang cepat, surat, tulisan dan segala sesuatu yang disampaikan 
kepada orang lain. Sedangkan asal kata wahyu secara bahasa adalah segala pemberitahuan yang bersifat samar atau rahasia (Nur Faizah, 2008: 35).

Pengertian wahyu dalam beberapa arti bahasa yang lain meliputi : (a) Ilham sebagai bawaan dasar manusia, seperti wahyu terhadap ibu Nabi Musa: " Dan Kami ilhamkan kepada ibu Musa, "Susuilah dia.." (QS. Al-Qasas: 28: 7) (b) Ilham yang berupa naluri pada binatang, seperti wahyu kepada lebah: "Dan Tuhanmu telah mewahyukan kepada lebah: 'Buatlah sarang dibukit-bukit, dipohon-pohon kayu, dan dirumah-rumah yang didirikan manusia”. (an-Nahl, 16: 68) (c) Isyarat yang cepat melalui rumus dan kode, seperti isyarat Zakariya yang diceritakan Quran : " Maka keluarlah dia dari mihrab, lalu memberi isyarat kepada mereka: 'Hendaklah kamu bertasbih diwaktu pagi dan petang”. (Maryam. 19: 11) (d) Bisikan dan tipu daya setan untuk menjadikan yang buruk kelihatan indah dalam diri manusia." Sesungguhnya syaitan-syaitan itu membisikkan kepada kawan-kawannya agar mereka membantah kamu”. (QS. Al-an`am, 6: 121) (e) Sesuatu yang disampaikan Allah kepada para malaikat-Nya berupa suatu perintah untuk dikerjakan. " Ingatlah ketika Tuhanmu mewahyukan kepada para malaikat: 'Sesungguhnya Aku bersama kamu, maka teguhkanlah pendirian orang orang yang beriman”. (QS. Al-Anfal, 8: 12) (Manna Khalil al-Qattan, 1996:37).

Sedangkan wahyu Allah secara terminologi atau (syara') adalah: Kalam Allah yang diturunkan kepada seorang Nabi. Berikutnya ustadz Muhammad Abduh memberikan definisi wahyu dalam Risalatut Tauhid sebagai berikut: Pengetahuan yang didapati seseorang dari dalam dirinya dengan disertai keyakinan pengetahuan itu datang dari Allah, baik melalui perantara atau tidak, yang pertama melalui suara yang terjelma dalam telinganya atau tanpa suara sama sekali.

Di sini beda antara wahyu dengan ilham. Ilham adalah intuisi yang diyakini jiwa sehingga terdorong untuk mengikuti apa yang diminta, tanpa mengetahui dari mana datangnya. Seperti rasa lapar, haus, sedih dan senang. Sedangkan wahyu adalah Kalam Allah yang diturunkan kepada seorang Nabi atau Rasul-Nya untuk disampaikan kepada umatnya. 


\section{Kemungkinan Terjadinya Wahyu}

Berbicara tentang fenomena pewahyuan bagi kita orang yang beriman, maka tidak kalah pentingnya mempelajari perkembangan ilmu pengetahuan yang semakin maju dalam bidang iptek dizaman modern sekarang ini. Perkembangan ilmiah telah begitu maju dengan pesat, dan cahayanya pun telah membuktikan dan menjawab semua keraguan yang selama ini merayap dalam diri manusia mengenai roh yang ada dibalik materi. Ilmu materialistis yang meletakkan sebagian besar dari yang ada di bawah percobaan dan eksperimen percaya terhadap dunia goib yang berada dibalik dunia nyata ini, dan percaya pula bahwa alam gaib itu lebih rumit dan lebih dalam daripada alam yang nyata.

Disamping itu sebagian besar penemuan modern yang membimbing akal pikiran manusia dapat menyembunyikan rahasia yang samar dan pada hakikatnya tidak bisa dipahami oleh ilmu itu sendiri, meskipun pengaruh dan gejalanya dapat

dipahami dan diamati. Hal semacam ini dapat mendekatkan jarak antara pengingkaran terhadap agama-agama dengan akidah keimanan seseorang (Manna Khalil al-Qattan, 1996:32). Dari sini dapat kita perkuat dengan firman Allah yang artinya sebagai berikut :

Kami akan memperlihatkan kepada mereka tanda-tanda (kekuasaan) Kami di segala wilayah bumi dan pada diri mereka sendiri, hingga jelas bagi mereka bahwa Al Quran itu adalah benar. Tiadakah cukup bahwa Sesungguhnya Tuhanmu menjadi saksi atas segala sesuatu? (QS. Fushshilat, 41: 53)

Dan firman Allah yang lain :

Dan tidaklah kamu diberi pengetahuan melainkan sedikit”. (QS. Al-Isra', 17: 85) 
Dari beberapa ayat diatas memberikan pengertian kepada kita bahwa pembahasan tentang psikologi dan ilmu jiwa kini mempunyai tempat yang penting dalam ilmu pengetahuan. Hal ini didukung dan diperkuat oleh perbedaan manusia dalam kecerdasan, kecenderungan dan naluri mereka. Diantara inteligensi itu ada yang istimewa dan cemerlang sehingga dapat menemukan segala yang baru. Disamping itu ada pula yang dungu dan sukar memahami urusan yang mudah sekalipun. Diantara dua macam posisi ini, terdapat banyak tingkatan kalau dihubungkan dengan ilmu jiwa. Yaitu ada yang jernih dan cemerlang, dan ada pula yang kotor dan gelap.

Dibalik tubuh manusia ada roh yang merupakan rahasia hidupnya. Apabila tubuh itu kehabisan tenaga dan energi serta jaringan-jaringan mengalami kerusakan jika tidak mendapatkan makanan menurut kadarnya, demikian juga roh sama seperti tubuh. Ia memerlukan makanan yang dapat memberikan tenaga rohani agar ia dapat memelihara sendi-sendi dan ketentuan lainnya.

Bagi Allah bukan hal yang jauh dalam memilih dari antara hamba-Nya sejumlah jiwa yang dasarnya begitu jernih dan kodrat yang lebih bersih serta siap menerima sinar illahi dan wahyu dari langit serta hubungan dengan makhluk yang lebih tinggi, agar kepadanya diberikan risalah illahi yang dapat memenuhi keperluan manusia. Mereka memiliki ketinggian rasa keluhuran budi dan kejujuran dalam menjalankan hukum. Mereka itu para Rasul dan Nabi Allah. Maka tidak aneh bila mereka berbuhungan dengan wahyu yang datang dari langit (Manna Khalil al-Qattan, 1996:1).

Manusia kini telah menyaksikan adanya hipnotis yang menjelaskan bahwa hubungan jiwa manusia dengan kekuatan yang lebih tinggi itu menimbulkan pengaruh. Hal semacam ini yang mendekatkan orang kepada pemahaman tentang gejala adanya wahyu. Orang yang berkemauan lebih kuat dapat memaksakan kemauannya kepada orang yang lebih lemah, sehingga yang lemah ini tertidur pulas dan kemudian ia menurut kehendaknya sesuai dengan isyarat yang diberikan, maka mengalirlah semua itu kedalam hati sanubari dari mulutnya. Apabila ini yang 
diperbuat manusia terhadap sesama manusia , bagaimana pula dengan yang lebih kuat dari manusia itu, yaitu Allah Rabbi yang menuntun manusia ke jalan yang benar.

Sekarang orang dapat mendengarkan percakapan yang direkam dan dibawa oleh gelombang udara, menyebrangi lembah dan dataran tinggi, daratan dan lautan tanpa melihat si pembicara, bahkan sesudah mereka meninggal. Kini dua orang dapat berbicara melalui telpon, HP dan alat lainnya, sekalipun seorang berada di ujung timur dan yang lain di ujung barat, sementara orang-orang yang duduk disekitarnya tidak mendengarkan isi pembicaraan selain gemuruh seperti suara lebah, dan itu persih seperti gemuruh diwaktu turunnya wahyu. Demikian contoh-contoh yang dapat menjelaskan kepada kita tentang hakikat wahyu (Manna Khalil al-Qattan, 1996:34).

Rasulullah SAW bukanlah Rasul pertama yang diberi wahyu. Allah telah memberikan juga wahyu kepada rasul-rasul sebelum itu seperti apa yang diwahyukan kepadanya. Seperti firman Allah yang artinya berikut ini :

Sesungguhnya Kami telah menyampaikan wahyu kepadamu seperti Kami telah menyampaikan wahyu kepada Nuh dan Nabi-nabi yang kemudian, dan Kami telah menyampaikan wahyu pula kepada Ibrahim, Ismail, Ishak, Ya`qub dan anak cucunya, Isa, Ayub, Yunus, Harun dan Sulaiman. Dan Kami berikan Zabur kepada Daud. Dan Kami telah mengutus Rasul-rasul yang sungguh telah Kami kisahkan tentang mereka kepadamu. Dan Allah telah berbicara kepada Musa dengan langsung”( QS. An-Nisa,4: 163-164).

Dengan demikian akan menjadi jelas, bahwa para Nabi yang nama-namanya disebut secara khusus dalam ayat diatas adalah mereka yang paling dikenal dikalangan Bani Israil. Berita tentang mereka diketahui benar oleh para ahli kitab yang mukim dekat Rasulullah SAW. Yaitu Hijaz dan kawasan sekitarnya. Karena itu Qur`an secara cermat menamakan apa yang diturunkan Allah kedalam hati Nabi Muhammad sebagai wahyu, yaitu suatu lafadz yang mengandung keseragaman makna wahyu yang diturunkan kepada semua Nabi dan rasul (subhi al-shalih, 1996: 20). 
Dengan demikian, maka wahyu yang diturunkan kepada Nabi Muhammad SAW itu bukan satu hal yang menimbulkan rasa heran. Oleh sebab itu Allah mengingkari rasa heran ini bagi orang-orang yang berakal.

\section{Cara Wahyu Allah Diturunkan kepada Malaikat}

Pertama, Di dalam al-Qur`an terdapat nas mengenai kalam Allah kepada para Malaikat-Nya yang artinya berikut ini, seperti : Artinya : "Ingatlah ketika Tuhanmu berfirman: 'Sesungguhnya Aku hendak menjadikan seorang khalifah dimuka bumi'. Mereka berkata: ' Mengapa Engkau hendak menjadikan khalifah di bumi itu orang yang akan membuat kerusakan didalamnya...?”. (QS. Al-Baqarah, 2: 30)

Ayat diatas dengan tegas menjelaskan bahwa Allah berbicara kepada para malaikat tanpa perantaraan dan dengan pembicaraan yang dapat dipahami oleh para malaikat itu.

Kedua, Telah nyata bahwa Qur`an telah dituliskan di lauhul mahfudz. Berdasarkan firman Allah sebagai berikut : Artinya: " Bahkan ia adalah Quran yang mulia yang tersimpan di lauhul mahfudz”. (QS. Al-Buruj, 85: 21-22)

Para ulama berpendapat mengenai cara turunnya wahyu Allah yang berupa Qur`an kepada Jibril dengan beberapa pendapat: 1) Malaikat Jibril menerima secara pendengaran dari Allah langsung dengan lafalnya yang khusus. 2) Malaikat Jibril menghafalnya dari lauhul mahfudz. 3) Bahwa maknanya disampaikan kepada malaikat Jibril, sedang lafalnya dari lafal Jibril, atau lafal Muhammad SAW. (Manna Khalil al-Qattan, 1996:42).

Dari beberapa pendapat diatas, maka pendapat pertama yang benar, dan pendapat itu dijadikan pegangan oleh Ahlus Sunnah wal-Jama'ah, serta diperkuat oleh hadis Nabi. Qur`an adalah kalam Allah dengan lafalnya, bukan kalam jibril atau kalam Muhammad. Sedangkan pendapat kedua diatas tidak dapat dijadikan pegangan. 
Sebab adanya Qur`an di lauhul mahfudz itu seperti hal-hal gaib yang lain, termasuk Qur`an.

Dan pendapat ketiga lebih sesuai dengan hadis, sebab hadis itu wahyu dari Allah kepada Jibril, kemudian kepada Muhammad SAW secara maknawi saja. Lalu hal itu diungkapkan dengan ungkapan beliau sendiri. Seperti friman Allah. Artinya : “Dia (Muhammad) tidaklah berbicara menurut kemauan hawa nafsunya. Apa yang diucapkannya itu tidak lain adalah wahyu yang diwahyukan kepadanya”. (QS. AnNajm, 53: 3-4) (Manna Khalil al-Qattan, 1996:871).

Dari ayat diatas maka dapat dijelaskan bahwa diperbolehkan meriwayatkan hadis Nabi menurut maknanya, sedangkan Qur`an tidak boleh. Maka dari itu bahwa keistimewaan Qur`an antara lain : pertama, Qur`an adalah mukjizat,. Kedua, kepastiannya mutlak. Ketiga, membacanya dianggap ibadah. Keempat, wajib disampaikan dengan lafalnya. Sedangkan hadis Nabi tidak sama.

Hadis nabawi ada dua macam : pertama, merupakan ijtihad Rasulullah SAW dan ini bukanlah wahyu. Pengakuan wahyu terhadapnya dengan cara membiarkan, bila ijtihad itu benar. Kedua, maknanya diwahyukan, sedangkan lafalnya dari Rasulullah sendiri. Ini termasuk hadis kudsi menurut pendapat yang kuat (Manna Khalil al-Qattan, 1996:1).

\section{Cara Penyampaaian Wahyu Allah kepada para Rasul}

Allah memberikan wahyu kepada para rasul-Nya ada dua macam. Pertama, melalui perantaraan. Kedua, ada yang tidak melalui perantaraan atau langsung. a) Melalui perantara, yaitu melalui malaikat Jibril. Malaikat pembawa wahyu. b) Tidak melalui perantara, yaitu melalui mimpi yang benar dalam tidur. Contoh mimpi yang benar dalam tidur:

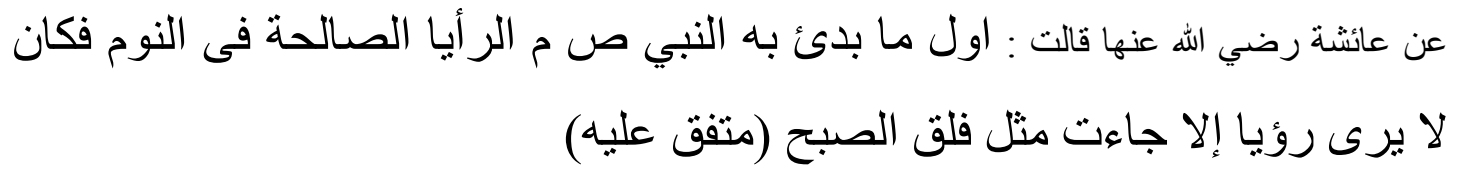


Artinya: "Dari Aisyah ra. Berkata: Sesungguhnya apa yang mula-mula terjadi bagi Rasulullah saw adalah mimpi yang benar diwaktu tidur. Beliau tidaklah melihat mimpi kecuali mimpi itu datang bagaikan terangnya pagi hari”.

Mimpi yang benar tidak hanya khusus bagi para rasul dan Nabi saja, melainkan orang awam dan kaum mukminin, sekalipun mimpi itu bukan wahyu. Seperti sabda Rasulullah saw.

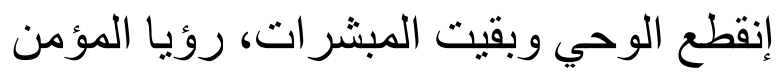

Artinya : "Wahyu telah terputus, tetapi berita-berita gembira tetap ada, yaitu mimpi orang mukmin".

Adapun cara penyampaian wahyu melalui perantara malaikat kepada Rasul ada dua macam.

Pertama, datang kepadanya suara seperti lonceng dan suara yang amat kuat yang mempengaruhi faktor kesadaran, sehingga ia dengan segala kekuatannya siap menerima pengaruh itu. Cara ini yang paling berat bagi Rasul.

Kedua, Malaikat menjelma kepada Rasul sebagai seorang laki-laki dalam bentuk manusia. Cara yang demikian ini lebih ringan dari pada cara sebelumnya, karena ada persamaan antara pembicara dengan pendengar. Dan rasul merasa senang sekali karena merasa seperti seorang manusia yang berhadapan dengan saudaranya sendiri (Manna Khalil al-Qattan, 1996:1). Keadaan Jibril menampakkan diri seperti seorang laki-laki itu tidaklah mengharuskan ia melepaskan sifat kerohaniaannya. Dan tidak berarti dzatnya berubah menjadi laki-laki. Tetapi yang dimaksudkan ialah bahwa ia menampakkan diri dalam bentuk manusia tadi adalah untuk menyenangkan diri Rasulullah sebagai manusia.

\section{Permulaan Wahyu dan Mu’jizat al-Qur`an}

Sosok figur dan kepribadian Nabi Muhammad memang sudah dipersiapkan secara bertahap, suatu masa yang penuh kebimbangan dalam melihat berbagai kejadian dan visi pandangan yang ada. Disamping itu juga ikut ambil bagian dalam 
mempersiapkan kematangan jiwanya dimana Jibril berulang kali hadir memperkenalkan diri. Pertama kali muncul di depan Nabi Muhammad saat ia berada di Gua Hiro, Jibril minta membaca dan beliau mengatakan tidak tahu. Kemudian malaikat mengulangi permintaannya tiga kali dan ia menjawab dalam keadaan serbabingung dan ketakutan sebelumnya, mengetahui kenabian yang tak terduga dan pertama kali mendengar al-Qur`an yang berbunyi :

Bacalah dengan (menyebut) nama Tuhanmu Yang menciptakan, Dia telah menciptakan manusia dari segumpal darah. Bacalah, dan Tuhanmulah Yang Maha Pemurah, Yang mengajar (manusia) dengan peraantaraan kalam”.(QS. Al-Qalam, 96: 1-5)

Setelah ayat tersebut diterima oleh diri Rasulullah, terjadilah sesuatu yang mengejutkan dengan perasaan dan melihat sesuatu yang tak pernah terlintas dalam pikirannya tentang tugas tersebut (saleh, 2009: 263). Nabi Muhammad kembali dalam keadaan gemetar menemui Khatijah minta agar dapat menghibur dan mengembalikan ketenangan jiwanya (Mm. al-A`zami, 2005:51). Sebagai orang Arab, tentu ia paham susunan ekspresi syair dan prosa, akan tetapi tak terlintas di otak sama sekali tentang ayat-ayat wahyu al-Quran yang ia terimanya. Sesuatu yang tak pernah terdengar sebelumnya serta susunan kata-kata yang tak ada bandingannya (Quraish Shihab, 1997: 26).

Al-Quran sebagai mukjizat terbesar yang pertama ia terima. Pada suatu waktu ditempat yang berbeda, nabi Musa diberi mukjizat sinar cahaya memancar dari tangan, tongkat menjadi ular raksasa sebagai tanda kenabiannya. Berbeda dengan peristiwa yang dialami Nabi Muhammad dari gua dalam sebuah gunung, malaikat meminta sibuta huruf agar membacanya. Mukjizatnya bukannya seekor ular naga, benda logam, kemahiran menyembuhkan penyakit, melainkan kata-kata ajaib yang tak pernah terlintas ditelinga siapa pun orangnya (Mm. al-A`zami, 2005:51).

\section{Nilai Pendidikan Penurunan Qur`an Secara Berangsur-angsur}


Agama Islam yang kita ikuti dan dianut oleh ratusan juta kaum muslimin diseluruh dunia, merupakan way of life yang menjamin kebahagiaan hidup pemeluknya di dunia dan diakhirat kelak. Ia mempunyai satu sendi utama yang esensial, berfungsi memberikan petunjuk kejalan yang benar dan selamat.

Allah berfirman yang artinya, Sesungguhnya al-Qur`an ini memberi petunjuk menuju jalan yang sebaik-baiknya (QS. 17: 9) (Quraish Shihab, 1997: 45).

Al-Qur`an memberikan petunjuk dalam persoalan akidah, syariah, dan akhlak, dengan jalan meletakkan dasar-dasar prinsip mengenai persoalan tersebut, dan Allah SWT menugaskan Rasulullah SAW untuk memberikan keterangan yang lengkap mengenai dasar-dasar itu. Firman Allahyang artinya:

Kami telah turunkan kepadamu Al-Dzikr (al-Quran) untuk kamu terangkan kepada manusia apa-apa yang diturunkan kepada mereka agar mereka berfikir". (QS. 16: 44) (Quraish Shihab, 1997: 45)

Maksud disini adalah bahwa Allah menurunkan Qur`an kepada Nabi Muhammad SAW untuk memberi petunjuk kepada manusia. Turunnya Qur`an merupakan peristiwa besar yang sekaligus menyatakan kedudukannya bagi penghuni langit dan penghuni bumi. Turunnya Qur`an yang pertama kali pada malam lailatul qadar merupakan pemberitahuan kepada alam tingkat tinggi yang terdiri dari para malaikat akan kemuliaan umat Muhammad. Umat ini telah dimuliakan oleh Allah dengan risalah baru agar menjadi umat yang paling baik bagi manusia.

Sedangkan turunnya Qur`an yang kedua kali secara bertahap, berbeda dengan kitab-kitab yang turun sebelumnya. Rasulullah tidak menerima risalah yang besar ini sekaligus, dan kaumnya pun tidak puas dengan risalah tersebut karena kesombongan dan permusuhan mereka. Oleh karena itu wahyu juga turun secara berangsur-angsur untuk menguatkan hati Rasulullah dan menghiburnya serta mengikuti peristiwa dan kejadian-kejadian sampai Allah menyempurnakan agama ini dengan nikmat-Nya (Manna Khalil al-Qattan, 1996:145).

Nilai-nilai pendidikan turunnya Qur`an secara berangsur-angsur selama 23 tahun adalah sebagai berikut firman Allah yang artinya, 
Artinya: "Dan Quran itu telah Kami turunkan dengan berangsur-angsur agar kamu membacakannya perlahan-lahan kepada manusia dan Kami menurunkannya bagian demi bagian”. (al-Isra', 17: 106)

Maksudnya : ayat tersebut menjelaskan turunnya Qur`an itu secara berangsurangsur agar kamu membacakannya kepada manusia secara perlahan-lahan dan teliti, dan Kami menurunkannya bagian demi bagian sesuai dengan peristiwa dan kejadian tertentu. Adapun kitab-kitab samawi lain, seperti Taurat, Injil dan Zabur, diturunkan sekali gus, tidak turun secara berangsur-angsur. Hal ini seperti firman Allah yang artinya,

"Dan berkatalah orang-orang kafir, 'Mengapa Quran itu tidak diturunkan kepadanya sekali turun saja?’. Demikianlah supaya Kami perkuat hatimu dengannya dan Kami membacakannya kelompok demi kelompok”. (al-Furqon, 25 :32)

Ayat ini menunjukkan bahwa kitab-kitab samawi yang terdahulu itu diturunkan sekaligus. Dan inilah pendapat jumhur ulama yang dijadikan pegangan (Manna Khalil al-Qattan, 1996:1). Seandainya kitab-kitab terdahulu turun secara berangsur-angsur, maka orang kafir tidak akan merasa heran terhadap Qur`an yang diturunkan secara berangsur-angsur.

\section{Hikmah Qur`an Diturunkan Secara Bertahap}

1. Untuk memperkuat hati dan jiwa Rasulullah saw.

Rasulullah SAW telah menyampaikan dakwahnya kepada manusia, tetapi ia banyak menghadapi sikap mereka yang menantang, membangkang dan watak mereka yang begitu beringas dan keras. Ia ditantang oleh orang-orang yang berhati keras, berperangi kasar, dan keras kepala. Mereka senantiasa melemparkan berbagai macam gangguan dan ancaman kepada Rasulullah. Padahal diri Rasul dengan hati tulus ingin menyampaikan segala yang terbaik kepada mereka.

Dari kejadian di atas, maka wahyu Allah turun kepada Rasulullah SAW dari waktu kewaktu sehingga dapat meneguhkan hatinya atas dasar kebenaran dan memperkuat kemauannya untuk tetap melangkahkan kakinya di jalan dakwah dengan 
tanpa menghiraukan perlakuan jahil, beringas, dan kasar yang dihadapinya dari masyarakatnya sendiri, karena yang demikian itu hanyalah merupakan kabut dan rintangan dimusim panas yang segera akan berakhir (Manna Khalil al-Qattan, 1996:1).

2. Tantangan dan mukjizat

Orang musyrik senantiasa berbuat dalam kesesatan dan kesombongan hingga melampui batas. Mereka sering mengajukan pertanyaan-pertanyaan dengan maksud melemahkan dan menantang untuk menguji kenabian Rasulullah. Mereka juga sering menyampaikan kepadanya hal-hal batil yang tak masuk akal, seperti menanyakan tentang hari kiamat, tentang roh dan minta disegerakan azab. Maka turunlah Qur`an dengan ayat yang menjelaskan kepada mereka segi kebenaran dan memberikan jawaban yang amat jelas atas pertanyaan mereka.

Contoh firman Allah yang artinya:

Artinya : " Dan tidaklah orang-orang kafir itu datang kepadamu dengan membawa sesuatu yang ganjil, melainkan Kami datangkan kepadamu sesuatu yang benar dan yang paling baik penjelasannya”. (QS. Al-Furqan, 25: 33)

Maksud ayat diatas ialah setiap mereka datang kepadamu dengan pertanyaan yang aneh-aneh dari banyak pertanyaan yang sia-sia, maka Kami datangkan kepadamu jawaban yang benar dan sesuatu yang lebih baik maknanya dari pada pertanyaan yang hanya merupakan contoh sia-sia saja.

Mereka di saat keheranan terhadap turunya Qur`an secara berangfsur-angsur, maka Allah menjelaskan kepada mereka kebenaran hal tersebut, sebab tantangan kepada mereka dengan Qur`an yang diturunkan secara berangsur-angsur sedangkan mereka tidak sanggup untuk membuat yang serupa dengannya. Hal ini akan lebih memperlihatkan kemukjizatan Qur`an dan lebih efektif pembuktiannya dari pada kalau Qur`an diturunkan sekaligus lalu mereka diminta membuat yang serupa dengan itu (Manna Khalil al-Qattan, 1996:1).

3. Untuk mempermudah Hafalan dan Pemahaman 
Al-Qur`an turun ditengah-tengah umat yang ummi, tidak pandai membaca dan menulis. Mereka mengandalkan sistem hafalan dan daya ingatan yang tinggi. Mereka tidak mempunyai pengetahuan tentang tata cara membaca, menulis dan pembukuan yang dapat memungkinkan mereka dapat menuliskan dan membukukannya, kemudian menghafal dan memahaminya.

Contoh firman Allah, yang artinya:

" Dialah yang mengutus kaum yang buta huruf seorang Rasul diantara mereka, yang membacakan ayat-ayat-Nya kepada mereka, mensucikan mereka, dan mengajarkan kepada mereka kitab dan hikmah, Dan sesungguhnya mereka sebelumnya benar-benar dalam kesesatan yang nyata”. (al-Jumu`ah, 62: 2)

Disini dapat kita renungkan bersama bahwa, Umat yang buta huruf itu tidaklah mudah untuk menghafal seluruh isi kandungan Qur`an. Seandainya Qur`an itu diturunkan sekaligus kepada beliau Nabi Muhammad saw, maka apa yang terjadi yaitu, tidak mudah bagi mereka untuk memahami maknanya dan memikirkan ayatayatnya. Maka turunnya Qur`an secara berangsur-angsur itu merupakan pelajaran berharga bagi umat Islam dan bantuan terbaik bagi mereka yang ingin untuk menghafal dan memahami isi kandungan ayat-ayatnya.

Setiap kali turun ayat atau beberapa ayat, maka para sahabat segera menghafal dan menuliskannya, memikirkan maknanya dan mempelajari hukum-hukumnya. Tradisi semacam ini sudah menjadi metode pengajaran pada masa sahabat dan tabi in.

4. Sesuai dengan Peristiwa yang terjadi dan Pentahapan dalam Penetapan Hukum Manusia pada masa itu tidak akan mudah mengikuti dan tunduk kepada agama baru. Dan Qur`an menghadapi mereka dengan cara yang bijaksana dan memberikan kepada mereka obat penawar yang ampuh untuk menyembuhkan mereka dari kerusakan dan kerendahan martabat. Setiap kali terjadi suatu peristiwa diantara mereka, maka turunlah hukum mengenai peristiwa itu yang memberikan kejelasan statusnya, petunjuk dan meletakkan dasar-dasar undang-undang bagi mereka, sesuai 
dengan situasi dan kondisi, satu demi satu. Dengan cara yang demikian ini menjadikan obat bagi hati mereka yang beriman (Manna Khalil al-Qattan, 1996:172).

Al-Qur`an pada mulanya meletakkan dasar-dasar keimanan kepada Allah, malaikat-malaikat-Nya, kitab-kitab-Nya, rasul-rasul-Nya dan hari qiyamat. Untuk itu, Qur`an menegakkan dengan bukti-bukti dan alasan sehingga kepercayaan terhadap berhala berkurang dari jiwa mereka orang-orang musrik dan sebagai gantinya adalah akidah Islam.

Kemudian dalam Qur`an juga mengajarkan akhlak mulia, menjelaskan kaidah halal dan haram yang menjadi dasar agama, dan penetapan hukum bagi umatnya, kemudian meningkat kepada penanganan penyakit sosial yang sudah mendarah daging dalam jiwa mereka. Hal-hal tersebut diatas, semua mempunyai dalil berupa nas al-Qur`an kemudian di jelaskan melalui sunah Rasulullah SAW (Manna Khalil al-Qattan, 1996:174).

\section{Hikmah Turunnya Qur`an Secara Bertahap dalam Pendidikan}

Dalam pendidikan dan pengajaran ada sebuah proses yang harus dilalui, yaitu;

1) Perhatian terhadap tingkat pemikiran pendidikan siswa. 2) perhatian terhadap pengembangan potensi akal, jiwa dan jasmani siswa dengan potensi yang dapat membawanya kearah perbaikan dan kebenaran.

Hikmah turunnya Qur`an secara bertahap itu merupakan suatu metode yang berfaidah bagi kita untuk mengaplikasikan kedua proses tersebut yang harus dilalui. Sebab turunnya Qur`an secara bertahap dan bersifat alami itu dapat meningkatkan mutu pendidikan bagi kita umat Islam untuk memperbaiki jiwa manusia, meluruskan prilakunya, membentuk kepribadian dan menyempurnakan eksistensinya sendiri. Oleh karena itu jiwa akan tumbuh dengan baik, dan tegak diatas pilar yang kokoh dan mendatangkan buah dan hasil yang baik bagi kepentingan dan kemaslahatan umat manusia seluruhnya dengan izin Allah.

Pentahapan turunnya Qur`an itu merupakan bantuan yang paling baik bagi jiwa manusia dalam upaya untuk menghafal Qur`an, memahami, mempelajari, 
memikirkan makna-maknanya dan mengamalkan apa yang ada dalam isi kandungan Qur`an. Diantara celah-celah turunnya Qur`an yang pertama kali didapatkan perintah untuk membaca dan belajar dengan alat tulis. Yaitu seperti firman Allah yang artinya sebagai berikut : "Bacalah dengan menyebut nama Tuhanmu yang telah menciptakan, Dia telah menciptakan manusia dari segumpal darah, bacalah, dan Tuhanmulah Yang Maha Pemurah, Yang mengajarkan manusia dengan perantaraan kalam”. (QS. Al-Qalam, $96: 1-5)$

Demikian juga dalam turunnya ayat-ayat tentang riba dan warisan dalam sistem harta kekayaan, serta turunnya ayat tentang peperangan untuk membedakan secara tegas antara Islam dengan kemusyrikan. Itu semua terdapat tahapan-tahapan pendidikan yang mempunyai berbagai cara dan sesuai dengan tingkat perkembangan masyarakat Islam yang sedang dan senantiasa berkembang, dari posisi yang lemah menjadi kuat dan tangguh (Manna Khalil al-Qattan, 1996:177).

Sistem belajar mengajar yang tidak memperhatikan tingkat pemikiran siswa dalam tahap-tahap pengajaran, bentuk bagian -bagian ilmu diatas yang bersifat menyeluruh, dan tidak memperhatikan pertumbuhan aspek-aspek kerpibadian yang bersifat intelektual, rohani dan jasmani, maka ia adalah sistem pendidikan yang gagal dan tidak akan memberi hasil terhadap ilmu pengetahuan kepada umat manusia, selain hanya akan menambah kebodohan, kemunduran dan keterbelakangan wawasan terhadap siswa, anak didik atau murid.

Seorang pendidik atau guru yang tidak memberikan kepada para siswa dan muridnya porsi materi pengetahuan yang sesuai, maka akan hanya menambah beban kepada mereka diluar kemampuan dan kesanggupannya untuk menghafal dan memahami. Dan berbicara kepada mereka dengan sesuatu yang tidak dapat mereka jangkau, atau tidak memperhatikan keadaan mereka dalam menghadapi perubahan yang aneh dan ganjil atau kebiasaan buruk mereka, sehingga ia berlaku kasar, brutal, dan keras serta menangani urusan tersebut dengan tergesa-gesa, tidak bertahap dan bijaksana, maka guru yang berlaku demikian ini adalah guru atau pendidik yang telah gagal. Dia mengubah proses kegiatan belajar mengajar menjadi kesesatan yang 
membahayakan dan menjadikan proses belajar mengajar yang tidak disenangi siswa atau murid.

Dengan demikian, petunjuk dari Allah tentang hikmah turunnya Quran secara bertahap adalah merupakan contoh yang baik untuk menyusun kurikulum dan silabi pengajaran yang tepat, memilih metode yang cocok dan baik serta menyusun buku pelajaran yang tepat sasaran (Manna Khalil al-Qattan, 1996:77).

\section{Penutup}

Dari beberapa pembahasan yang telah kita sampaikan diatas tentang sejarah singkat Quran akan membuka cakrawala baru kita semuanya untuk selalu membaca, mengkaji dan memahaminya isi kandungan al-Qur`an dalam setiap kesempatan waktu yang ada. Disini dapat kita garis bawahi bahwa Qur`an merupakan wahyu Allah yang disampaikan kepada Nabi Muhammad SAW melalui malaikat Jibril dari lauhul mahfud. Disamping itu juga, Qur`an merupakan sumber dari beberapa ilmu pengetahuan yang harus selalu digali dengan cermat dan mendalam, karena akan dapat memunculkan ilmu-ilmu baru setelah diadakan penelitian dan kajian secara mendalam.

Al-Qur`an Diturunkan secara bertahap selama 23 tahun memberikan inspirasi pembelajaran bagi umat Islam untuk mudah dihafal dengan baik dan akan selalu mengikuti pada setiap kasus dilapangan yang dihadapi segera dapat ditemukan jawabannya dengan pasti dan benar. Kemudian sisi lain dari Al-Qur`an juga merupakan pedoman bagi seorang pendidik dalam menyampaikan suatu ilmu pengetahuan kepada siswa, peserta didik, atau murid yang dilakukan secara bertahap dan benar sesuai dengan tingkat usia anak didiknya.

Demikian gambaran singkat sejarah Quran yang dapat kami sampaikan kepada para pembaca dan pencinta ilmu pengetahuan. Kemudian penulis berharap kepada para pembaca artikel ini agar memberikan kritik, saran dan masukan pada isi makalah ini. Dan akhirnya nanti akan menjadi buah karya ilmiah yang berkualitas setelah anda memberikan masukan terhadap isi artikel ini. 


\section{Daftar Pustaka}

Depag.RI., al- Qur`an dan Terjemahannya, Jakarta, 1978.

Hasbi Ash-Shiddieqy, Sejarah dan Pengantar Ilmu Al-Quran/Tafsir, Bulan Bintang, Jakarta, 1980.

M. Quraish Shihab, Membumikan Al-Quran, Fungsi dan Peran Wahyu dalam kehidupan Masyarakat, Mizan, Bandung, 2009.

M. Quraish Shihab, Mukjizat al-Quran, Ditinjau dari Aspek Kebahasaan Isyarat Ilmiah dan Pembicaraan Gaib, Mizan, Bandung, 1997.

Manna Khalil al-Qattan, Studi Ilmu-ilmu Qur`an, Terj. Mudzakir AS, Litera Antar Nusa, Jakarta, 1996.

Mm. al-A`zami, Sejarah Teks al-Quran dari Wahyu sampai kompilasi Kajian Perbandingan dengan Perjanjian lama dan Perjanjian Baru, Gema Insani, Jakarta, 2005.

Nur Faizah, Sejarah al-Quran, Artha Rivera, Jakarta, 2008.

Shaleh, Asbabun Nuzul, Latar Belakang Historis Turunnyea Ayat-ayat al-Quran, Diponegoro, Bandung, 2009.

Subhi as-Shalih, Membahas Ilmu-ilmu al-Quran, Pustaka Firdaus, Jakarta, 1996. 